\title{
Solfatara, \\ czyli dziesięć dni rewolucji rybaka. Z Maciejem Henem rozmawia Ewa Tyszko
}

Ewa Tyszko: Dobry wieczór Państwu, mam zaszczyt i przyjemność poprowadzenia rozmowy z Maciejem Henem, autorem Solfatary. Trudno powiedzieć, że Maciej przyjechał do nas gościnnie, bo właściwie wrócił do domu...

Maciej Hen: Trochę tak. Mieszkałem w Łodzi przez osiemnaście lat, od 1975 do 1993 roku. W 1993 kiedy na chwilę, na trzy lata, dostałem pracę w redakcji Programu Trzeciego Polskiego Radia, wróciłem do Warszawy, z której pochodzę. I utknąłem. Nie powiem, że nie kocham Warszawy, ale do Łodzi mam sentyment.

ET: Przejdźmy do Twojej powieści. Czy Solfatara jest książką, która może działać na emocje? Seks, śmierć, miłość, morderstwa - to wszystko jest. To ewenement - nazywana jest powieścią historyczną, ale czy słusznie? Autor przenosi nas do siedemnastowiecznego Neapolu, jedno z ważnych kryteriów gatunku jest spełnione. Wolę jednak określenie „kronika", kupując tę książkę w ciemno, nie znając autora, można by pomyśleć, że to reprint powieści napisanej wiele lat temu.

MH: To wrażenie jest zamierzone, to efekt stylizacji, delikatnej na tyle - mam nadzieję - że nie utrudnia lektury. Mimo wszystko uważam, że to dość klasyczna powieść historyczna w tym sensie, że jej kanwą są wydarzenia wielkiej historii, przewijają się różne, niekoniecznie pierwszoplanowe postaci - mniej ważni książęta, wicekrólowie. Zresztą, jak na wicekróla, książę De Arcos jest ważną postacią. Widzimy i udzielnych książąt, i rozmaite autentyczne osobistości ze świata naukowego, artystycznego, intelektualnego tamtych czasów. Są różne zdarzenia, które odnotowano w ówczesnych kronikach i archiwach. Natomiast ja postawiłem sobie za cel

${ }^{1}$ Rozmowa odbyła się 25 października 2015 r. w łódzkim Domu Literatury. 
wypełnienie pewnych białych plam. Mam wrażenie, że udało mi się połączyć różne oderwane autentyczne postaci i wydarzenia, stworzyć z nich pewną działającą na czytelnika całość - fabułę. Fabułę z całą pewnością niejednorodną, „zbieraninę", a jednak, kiedy czytam różne recenzje, okazuje się, że uzyskałem efekt, o który mi chodziło. Nie wiem, jak to się stało, bo była to w dużym stopniu improwizacja. Przebudowywałem tę konstrukcje do ostatniej chwili, układałem jak z klocków lego, trochę zachęcony przez mojego wyjściowego (trudno nazwać go głównym) bohatera - François de Nomé, który tworzył fantastyczne kompozycje architektualne. Budował je z różnych elementów, fragmentów istniejących budowli, mieszając ze sobą różne style. I ja popełniam w tej książce coś podobnego.

\section{ET: Skąd wziął się pomysł na Solfatarę?}

MH: W 2004 wydałem roku pod pseudonimem powieść Wedtug niej, która nie została zauważona. Miała kilka recenzji, nawet pozytywnych, zdecydowanie krytycznych nie było. Przemknęła przez rynek, znikła bez śladu. Można powiedzieć, że był to niewypał. Sądziłem, że zasłużyła na więcej, na to żeby bardziej zaistnieć, ale już nic nie mogłem z tym zrobić. Zastanawiałem się kiedyś głośno w domu, czy jeszcze mogę tę książkę jakoś uratować. I wtedy moja żona Ania powiedziała mi tak: napisz następną książkę, zrób to tak, żeby nie przemknęła niezauważona. Wyciągnij wnioski z wszystkich taktycznych błędów, które popełniłeś. Zabrałem się do pisania Solfatary z myślą o tym, żeby wyciągnąć za uszy Wedtug Niej. Trzymam się tego planu, chociaż teraz Solfatara jest dla mnie ważniejsza, $\mathrm{z}$ wielu różnych względów: myślę, że to jest rzecz obszerniejsza, bogatsza. Teraz jestem chyba bardziej zaawansowany literacko. Kiedy pisałem Według niej, myślałem, że to będzie moja pierwsza i ostatnia książka, że to jedyna rzecz, którą mam do powiedzenia światu, tymczasem trzeba było obmyślić coś nowego. Żona mówiła: napisz o jakimś malarzu, przecież jesteś plastykiem z wykształcenia (kończyłem liceum plastyczne). $\mathrm{W}$ tamtym czasie miałem hysia na punkcie pewnego obrazu, o którym bardzo mało wiedziałem. Nie znałem nawet nazwiska autora, ponieważ w książce, w której był reprodukowany, był podpisany tajemniczym nazwiskiem Monsù Desiderio. Nie miałem pojęcia, kim był, w dodatku książka była po niemiecku, a ja nie byłem na tyle zaawansowany, żeby móc przeczytać opis. Chciałem napisać o kimś, kto wywinduje mnie, a jednocześnie ja jego - o kimś, kto nie był jeszcze wyeskploatowany i oczywisty jak Goya czy van Gogh. Kiedy wpisałem to nazwisko w internecie, okazało się, że Monsù Desideria nigdy nie było. Było dwóch Lotaryńczyków, których malarstwo przez jakiś czas, w pierwszej połowie dwudziestego wieku, było omyłkowo kwalifikowane jako dzieło tajemniczego Monsù Desideria, o którym wspomina autor osiemnastowiecznej monografii malarstwa neapolitańskiego, niejaki Bernardo de' Domenici, pisze tam: "Monsu Desiderio był mistrzem w malowaniu panoram i fantazji architektonicznych". I teraz dowiaduję się, że być może oni malowali razem, być może osobno. A może czasem razem, a czasem osobno. W każdym razie musieli się znać, ponieważ obaj pochodzili z tego samego miasta w Lotaryngii, z Metz, i obaj całe dorosłe życie spędzili w Neapolu. Jeden nazywał się François de Nomé, a drugi Didier Barra. Im bardziej się w to zagłębiałem, 
tym bardziej prowadziło mnie to do Neapolu. Kiedy dowiedziałem się więcej na ten temat, zrozumiałem, że w tej książce musi być nie tylko Neapol, ale i Metz, i Rzym, w którym dzieciństwo spędzał François de Nomé. Aby pomieścić ich obu, akcja powieści musiała się rozciągać aż do połowy XVII wieku, bo Didier Barra umarł prawdopodobnie w czasie wielkiej zarazy w roku 1656 roku, ale też w znacznej części rozgrywać się w pierwszych latach XVII wieku, ponieważ ostatni obraz podpisany przez François de Nomé powstał w 1623 roku. To samo mówią księgi bankowe, z których dowiedziałem się, że $w$ tamtych czasach funkcjonowały banki, przelewy bankowe. Transakcje pieniężne załatwiało się poprzez bank, a nie z ręki do ręki. Wiele rzeczy przebiegało bardzo podobnie jak współcześnie. Skoro odkryłem, że aby obu panów pomieścić, muszę pokazać Neapol w końcówce życia Didiera Barry i za życia François de Nomé, to jest fantastyczna okazja, żeby pokazać też rewolucję Masaniella, która jest najbarwniejszym epizodem historii Neapolu siedemnastego wieku. Ale żeby zmieścić w niej François de Nomé, który w momencie wybuchu rewolucji nie żył od dwudziestu paru lat, to musiałem popełnić retrospekcje. A skoro retrospekcje, to chyba najlepiej nada się do tego forma zapożyczona z Rękopisu znalezionego w Saragossie. Tak się składa, że to moja ulubiona lektura, dlaczego więc nie miałbym podjąć się takiej próby? I tak, krok za krokiem doszedłem i do Neapolu, i do innych miejsc, i do tego, że moim narratorem będzie ktoś inny, żaden z dwóch malarzy. Potem moi dwaj ukochani artyści odsunęli się na jeszcze dalszy plan, powieść zaczęła żyć własnym życiem, jej bohaterowie również. Dosyć szybko się zorientowałem, że to nie do końca będzie opowieść o powstaniu tego obrazu, który jednak występuje, odgrywa znaczącą rolę. Obaj panowie uczestniczą w konstrukcji fabularnej.

ET: Pomówmy jeszcze o fabule. Solfatara istnieje naprawdę, to wulkan. Jesteśmy w Neapolu, trwa rewolucja. Opisywana jest przez twojego bohatera - dziennikarza, człowieka po pięćdziesiątce, któremu daleko do herosa. Otyły, miewa kłopoty ze swoją gnuśną męskością, nie stroni od podejrzanych przybytków. Swój świat opisuje z dystansem, niekiedy $\mathrm{z}$ przerażeniem, bez wiary $\mathrm{w}$ powodzenie rewolucji.

MH: To nie brak wiary. On się lęka o to, co się stanie, jeśli rewolucja się uda. Faza, którą widzi i która go niepokoi, to faza ślepego entuzjazmu, zarówno mas, jak i lgnącej ku nim inteligencji. Entuzjazm ten wyraża się $\mathrm{w}$ przerażającym okrucieństwie i wandalizmie. Jednocześnie nasz bohater rozumie, że ta rewolucja dotyka czegoś istotnego. Jest zalążkiem zmiany na lepsze, która to zmiana - o czym dowiadujemy się z epilogu - nigdy nie nastąpiła. My natomiast, po czterech stuleciach, wiemy, że te wczesne rewolucje ludowe - głupie bo głupie - zapoczątkowały coś, co sprawiło, że bezwzględny świat feudalny zmienił się w świat demokratyczny, przynajmniej w Europie, w jej zachodniej części. Nie odbyło się to bez straszliwych paroksyzmów, ale ideał, to coś dobrego, co ma z tego powstać, już się wyłania. Oni widzieli to jeszcze bardzo mgliście, często błądzili. Nasz bohater trochę przeczuwa, że świat, do którego jest przyzwyczajony, wymaga gruntownej przemiany, ale jednocześnie przeraża go koszt tych przemian. Nie jest do końca przekonany, czy to wszystko zmierza we właściwym kierunku. 
ET: Twój bohater miał prawo się bać obserwując to wszystko, nie wiedział, jak się to skończy. My, znając finał, możemy zachować optymizm. Można powiedzieć, że wędrujemy w przeszłość jeszcze głębiej, ponieważ Twój bohater snuje historię swojego życia. Na każdym etapie opowieści słychać kogoś innego: chłopaka, młodzieńca, dojrzałego mężczyznę.

MH: Cieszę się, jeśli to się udało. Cały czas zadawałem sobie pytanie, czy stylizacja, którą sobie narzuciłem, nie sprawiła, że tekst jest zbyt jednolity pod względem sposobu widzenia rzeczywistości, rytmu zdania itd. Szczególnie obawiałem się tego, że wszyscy narratorzy będą mówili takim samym językiem.

ET: Udało się, zdecydowanie. Ponieważ narratorów jest kilku i wszyscy wprowadzają nas w historię swojego życia, nie jest to powieść, którą można czytać fragmentami, odkładając na jakiś czas. Można się pogubić - świat, który zbudowałeś jest wielowątkowy, bogaty w postaci, wydarzenia, detale. Dawno nie widziałam powieści tak dopracowanej. Pisałeś ją dziewięć lat, prawda?

MH: Tak, zajęło mi to dziewięć lat, ale muszę przyznać, że w tym czasie pracowałem dość intensywnie na etacie, robiłem sobie kilkumiesięczne przerwy na inne zajęcia zarobkowe, jak na przykład pilne tłumaczenia - w czasie pisania Solfatary przetłumaczyłem kilka książek. Gdybym mógł się utrzymywać wyłącznie z pisania powieści, wówczas być może Solfatara zajęłaby mi nie dziewięć lat, a trzy. Wracając do tego, co powiedziałaś, że najlepiej przeczytać Solfatarę jednym tchem, to rzeczywiście jest ideał, ale nie zawsze się udaje. W odniesieniu do cyklu Prousta Boy zalecał dostać grypy, obłożyć się książkami i czytać - od pierwszego do ostatniego tomu.

ET: Tak zwana choroba obłożna - obłożyć się książkami.

MH: Tak, rzeczywiście tak jest najlepiej, każdy autor o tym marzy, żeby czytelnik nie odrywał się od jego książki. Mimo wszystko, jeśli nawet ktoś się pogubi, to albo się odnajdzie, albo nie. Jeśli się nie odnajdzie, to będzie czytał dalej zagubiony, tak też można. Książka jest tak zrobiona, że można otworzyć ją na dowolnej stronie i jest ciekawie. Może to zabrzmi nieco zarozumiale, ale kiedy miałem napisany spory fragment, robiłem testy. Zaczynałem czytać od przypadkowo wybranej strony i kiedy było niedobrze, kiedy stwierdzałem, że mnie, autora zblazowanego już przecież własnym tekstem, to wcale tak bardzo nie emocjonuje, to znaczyło, że na pewno w tym miejscu tekst wymaga przepracowania. Starałem się tak przygotować ten tekst, żeby był w każdym miejscu ciekawy, niezależnie od tego, czy znamy kontekst, czy nie.

ET: A kiedy autor wie, że tekst jest gotowy i należy zakończyć wszystkie poprawki?

MH: Odpowiem najpierw na pierwszą część pytania, chociaż właściwie nie znam odpowiedzi: wtedy, kiedy plan, ostateczny konspekt, jest zrealizowany. W trakcie pisania konstrukcja może się zmieniać, pewne rzeczy się nie sprawdzają, inne spontanicznie idą w innym kierunku, trzeba się do tego dostosować. Kiedy zmierzałem do końca, miałem założoną żelazną konstrukcję, której się trzymałem. Cała teraźniejszość miała zamykać się w dziesięciu dniach rewolty, to, co potem może być najwyżej w posłowiu, 
a to co przedtem - to jest właściwie esencja tej książki. Chciałbym powiedzieć coś jeszcze, muszę zaznaczać to bardzo mocno, za każdym razem, gdy dorywam się do głosu. Rewolucja, teraźniejszość, jest tylko pretekstem do opowieści z przeszłości, które zresztą w pewnym momencie splatają się z teraźniejszością. Przeszłość dopada teraźniejszość. To opowieści z przeszłości są główną treścią mojej książki, nie można więc powiedzieć, że jej akcja rozgrywa się w Neapolu. Plan pierwszy, teraźniejszość książkowa, to jest Neapol w lipcu 1647 roku. To, co dla mnie jako autora jest najcenniejsze $\mathrm{w}$ tej książce, to wszystkie retrospekcje.

ET: Bohater opowiada o tym, kim jest, próbując samemu odpowiedzieć na to pytanie. Budujesz świat pełen detali: od tego, jak wyglądał wówczas system płatniczy, jak wyglądały uliczki w Neapolu, gdzie stały kościoły, jaka była pogoda danego dnia, w co byli ubrani ludzie. Mam za mało wiedzy historycznej, żeby móc ocenić, czy mówisz prawdę, czy nie, ale ten świat jest wiarygodny. Na ile te detale zostały przez ciebie pracowicie wygrzebane, a na ile zmyślone?

MH: Powiem tak: wszystko, do czego udało mi się dotrzeć, jest prawdziwe. Bardzo starałem się dotrzeć do pełnej wiedzy, odpowiedzieć sobie na wszystkie tego rodzaju pytania: jak ci ludzie żyli, jak korzystali z toalety, jak często się myli, czy rzeczywiście tak rzadko, co jedli, ile to kosztowało, skąd brali pieniądze, jak wyglądała topografia. I tak docierałem do wielu informacji. Dziś dzięki internetowi można wielu rzeczy się dowiedzieć, tylko trzeba sprawdzać, potwierdzać, bo wiele jest informacji bałamutnych. Poza tym na wiele pytań nie ma odpowiedzi, ale to są te białe plamy, o których mówię, trzeba wypełniać je własną domyślnością. Kilka razy spotkałem się z reakcją, że wątpliwości budzi wiarygodność pewnych informacji, na przykład że to przecież niemożliwe, że Fortunato miał zegarek, żeby ktoś nosił okulary lub mógł założyć w tamtym czasie gazetę.

ET: W Solfatarze występuje też postać księżniczki. Nie jest to postać z baśni, piękna, wiotka, blondwłosa. To pani w latach, niejednoznaczna piękność, o dwuznacznej moralności. I potrafi pływać. Czy księżniczka miała wówczas prawo umieć pływać?

MH: Myślę, że miała. Czytałem dość dużo o takiej miejscowości, która po łacinie nazywa się Baiae, a po włosku Baia. Trochę za Solfatarą, z piękną plażą. Tuż za linią brzegową, pod powierzchnią wody widać ruiny starożytnych budowli. W różnych książkach o historii Neapolu pisano, że od czasów starożytnych, przez średniowiecze, aż do czasów, które opisuję i prawdopodobnie później, było to ulubione miejsce wakacyjnego odpoczynku tamtejszej arystokracji i zamożniejszych ludzi. To miejsce było też znane z rozluźnienia obyczajów. Właśnie tam panie z arystokracji pływały w strojach, które musiały przypominać te, w których zażywały kąpieli w gorących źródłach: coś w rodzaju długiej koszuli, przez którą wszystko było widać. To akurat opisuje w swoim dzienniku podróży Michel de Montaigne, w ostatniej ćwiartce szesnastego wieku. I taki obrazek jest też w mojej książce. Skoro Donna Sveva mieszkała nad morzem i w dodatku jej rodzina miała zamek na wyspie Ischia w Zatoce Neapolitańskiej, w niewielkiej odległości od brzegu, to musiała pływać. W książce jest też scena, w której gra 
$\mathrm{w}$ tenisa lub w coś w rodzaju tenisa. To się nazywało pallonetto. Czy ona uprawiała ten sport? Być może trochę przesadziłem, pofolgowałem fantazji. Ale akurat w pałacu jej męża był kort do pallonetto, którego wielbicielem był jego ojciec - z tego właśnie zasłynął. Dlaczego więc miałaby nie grać? Jeżeli uprawiała tenisa, to dlaczego miałaby nie pływać? Niektóre panny, te bardziej śmiałe, jeździły wówczas konno. Krótko mówiąc, bywały dość wysportowane, zatem dlaczego nie.

ET: W Solfaterze jest i maść czarownic...

MH: Maśc czarownic jest calkowicie autentyczna. Celowo nie podałem przepisu, który istnieje. Po pierwsze zawiera składniki, co do tłumaczenia których są rozbieżności. To nazwy łacińskie, stylizowane, niejasne. Po drugie nie ma tam proporcji. Nie było dramaturgicznej potrzeby, żeby podawać ten przepis.

ET: Solfatara to także historia władzy, która dostała się w ręce rybaka wyniesionego na piedestał prawie jak święty, i tego, jakie demony potrafi z nas wyciągnąć.

MH: Tak, ktoś powie, że to nic odkrywczego. I ja się z tym zgodzę. Niczego nie odkrywam, to wszystko, to znaczy szczegóły poczynań Masaniella, są wzięte z obfitych materiałów źródłowych, które się zachowały. Uznałem za swój obowiązek, aby w tej książce, która jest konstrukcyjnie na nich oparta, umieścić jak najwięcej prawdy o przebiegu tych dziesięciu dni. Dziesiątego dnia Masaniello ginie w zamachu i wydaje się, że to koniec rewolucji. Jak się okazało później - bynajmniej, wszystko ciągnęło się jeszcze przez dziewięć miesięcy. W pamięci historycznej ludu neapolitańskiego przetrwało tych dziesięć dni. Na początku pracy nad książką pojechałem do Neapolu, żeby zobaczyć trochę topografii, poszukać ikonografii, trochę się zainspirować, po prostu. Pytałem napotkanych ludzi o różne miejsca, o to jak gdzieś dotrzeć, a oni mnie pytali, kim jestem. Mówiłem - z pewną nutą przechwałki - że jestem pisarzem z Polski i przyjechałem, bo będę pisać książkę. Niezależnie od tego, czy trafiałem na ludzi wykształconych, średnio wykształconych, czy kompletnie niewykształconych, za każdym razem na dźwięk imienia Masaniella twarze się rozjaśniały i już byliśmy przyjaciółmi. Mimo wszystko, on jest ich miejscowym bohaterem, po prawie czterystu latach. To jest ciągle żywe. Ta rewolucja to była sprawa lokalna i, co tu dużo gadać, kontrowersyjna. W ciągu dziesięciu dni zginęło około czterech tysięcy ludzi, w tym tylko jeden arystokrata. Reszta to byli cywile, służba arystokratów, jacyś muzycy, zwykli prości ludzie, których nagle oskarżono o zdradę, szpiegostwo, bandytyzm. Właściwi wrogowie, przeciwko którym wzniecona została ta rewolucja albo zdołali się schronić, albo doprowadzeni przed oblicze Masaniella byli puszczani wolno lub tylko internowani. Zachował respekt dla wyższej klasy i chyba upajał się swoja wielkodusznością.

ET: Pokazujesz go jako szaleńca. Można zapytać, czy to szaleństwo tkwi w nim od początku czy rozwija się? Czy dokumenty historyczne to potwierdzają?

MH: Właściwie opisuję to bardzo wiernie, tak jak było. Do dzisiaj istnieje spór, czy jego dziwne zachowanie nie było wywołane jakimś spiskiem 
- tym, że ktoś go podtruwał, narkotyzował. Zaczynał zachowywać się coraz dziwniej. Wydaje mi się, że ze względu na moral, który z tego wynika, najlepiej rozumieć to $w$ ten sposób, że był coraz bardziej odurzony władzą. Co ciekawe, baśniowy motyw żony rybaka, który pojawia się w mojej książce, również został przez kronikarzy odnotowany.

ET: Wróćmy do kwestii obyczajowych. Kiedy myślimy o historii, literaturze, wydaje nam się, że nasi przodkowie byli bardzo cnotliwi. Tymczasem świat twojej powieści tworzą ludzie sprośni, rozbuchani seksualnie, niezależnie od płci. Gdzie te cnotliwe damy? Gdzie szlachetni panowie?

MH: Chyba jednak bardziej chodzi o damy... Wiemy stosunkowo dobrze, że ówcześni panowie byli rozbuchani i nie bardzo się hamowali. Co do dam, one były spętane obyczajowością i regułami, których musiały przestrzegać, bo koszty nieposłuszeństwa bywały bardzo dotkliwe. Pewnie niektóre, o czym wiadomo z dzieł literackich czy historycznych, nic sobie z tego nie robiły. Jeśli zaś chodzi o Neapol, to czytamy u rozmaitych kronikarzy i dziejopisów, że miejscowe damy pozwalały sobie na bardzo wiele luzu - dokładnie na tyle, na ile pozwalali im ich mężczyźni. Krótko mówiąc, w Neapolu panowało zepsucie. Jego mieszkańcy byli bardziej podobni do współczesnych, niż byśmy podejrzewali. $\mathrm{W}$ obu moich książkach, poprzedniej i tej, wychodziłem z założenia, że zmieniają się kostiumy, języki, sposoby wysławiania się, zmienia się wiedza, konstrukcje społeczne, ale nie człowiek w swej istocie. Próbuje się odnaleźć w swych ograniczeniach, być sobą. Oczywiście, trudno być sobą w niektórych cywilizacjach, które narzucają ścisłe normy, na przykład kobieta $\mathrm{w}$ tradycyjnym islamie nie może zachowywać się z taką swobodą, jak w każdej innej kulturze czy środowisku neapolitańskim, o którym piszę. W dzienniku Montaigne'a czytamy, że Włoszki były o wiele mniej swobodne w sposobie bycia niż Francuzki. I właśnie dlatego, jeśli udało się z Włoszką porozmawiać, rozluźnić nieco tę barierę, która przeszkadzała jej rozmawiać z nieznajomymi, to bardzo szybko prowadziło do finału. Natomiast Francuzki, które według Montaigne'a mają bardziej swobodny sposób bycia, ograniczają się tylko do swobodnej rozmowy. Przełamanie tej bariery dla Włoszek oznacza złamanie wszelkich zasad, u Montaigne’a mamy tego przykłady. Czytając na przykład kompilacje Kazimierza Chłędowskiego o życiu ówczesnych Włoch, które były moimi pierwszymi lekturami na ten temat, komedie Giambattisty della Porty, analizując wiersze Marina, można dojść do wniosku, że nie wszystkie Włoszki były kobietami bardzo pilnującymi się i pilnowanymi.

ET: Jedną z bohaterek twojej powieści jest sztuka, zarówno muzyka, jak i malarstwo, literatura. Jeden bohaterów patrząc na obraz ocenia go tak - parafrazując: to jest dobre malarstwo, ale nie ma w nim muzyki.

MH: To mówi Fortunato, nasz główny narrator, który jest melomanem, trochę niespełnionym muzykiem. Na malarstwie trochę się zna, ale nie czuje się wielkim ekspertem, dlatego posługuje się wyrażeniem, które jest czytelne dla niego samego. muzyka.

ET: Ja $\mathrm{z}$ pełnym przekonaniem twierdzę, że $\mathrm{w}$ tej powieści jest 
MH: Dziękuję, starałem się. Ta książka jest też okazją do pokazania pewnych zjawisk artystycznych tamtej epoki, które są ciekawe, ale nie zostały tak szeroko spopularyzowane. Pojawiają się pewne wzmianki na przykład o Caravaggio, którego daty życia i miejsca przebywania częściowo zazębiają się z datami życia moich bohaterów. Siłą rzeczy, ponieważ był to artysta, o którym w tamtym czasie było bardzo głośno, wywarł ogromny wpływ na całą rzeszę naśladowców, nie dało się go pominąć. Poza tym, tak wielkiego artysty w ogóle nie dało się pominąć. Celowo odsunąłem go na dalszy plan, ponieważ na pierwszym planie są inni artyści. Jeden z nich jest moim prywatnym odkryciem.

Chciałbym opowiedzieć trochę o muzyce, której poświęciłem szczególnie dużo miejsca. Carlo Gesualdo, niezwykle barwna i kontrowersyjna postać. Jego muzyka jest dość trudna w recepcji. Jest też nierówna, są lepsze i gorsze momenty, ale na pewno zaskakująca jak na tę epokę. Prekursorem muzyki, która rozwijała się od XVII wieku, był Monteverdi. Słyszymy duży nacisk na linię melodyczną, na akompaniament, pewien wysiłek zabiegania o słuchacza. Można powiedzieć, że Gesualdo to biegunowe przeciwieństwo. To przede wszystkim muzyka polifoniczna, zawsze wielogłosowa, w której nie wiadomo, co jest akompaniamentem. Liczą się przede wszystkim współbrzmienia.

ET: Teraz rozumiem, dlaczego ta powieść ma dziewięćset stron - jesteś gadułą!

MH: Nie wiem, czy to zachęci tych, którzy jej nie czytali. W trakcie końcowych prac nad książką myślałem, co by z niej wyrzucić, co jest przegadane. Wykreśliłem kilka rzeczy z wczesnych rozdziałów, kiedy byłem jeszcze zorientowany $\mathrm{w}$ tym, jaki mam materiał, jak powinienien rozłożyć akcenty itd. $\mathrm{W}$ tych pierwszych rozdziałach starałem się upchnąc jak najwięcej i udowodnić sobie, że mam o czym pisać. Potem, kiedy wiedziałem, że i tak jest o czym pisać, pisałem oszczędniej i nie umieszczałem wszystkiego. Potem udało mi się odciążyć, lekko przetrzebić pierwsze rozdziały, pierwszych, powiedzmy, sto stron. Ze trzydzieści stron wyciąłem. Z tego co wiem, Olga Tokarczuk ze swojej książki ścięła jeszcze więcej, ponad sto stron. To dobra wróżba dla mnie. Bardzo szanuję Olgę Tokarczuk, chociaż mam inny temperament literacki, inny obraz świata. Ale łączą nas pewne sprawy, choćby grubość naszych książek. Jeszcze nie zabrałem się do jej powieści, nie dlatego, żebym się bał, czy nie miał chęci, ale z niektórych opisów i fragmentów, które slyszałem radiu wynika, że ona też stara się bardzo dotykalnie opisać świat, który przedstawia. Pod tym względem jesteśmy podobni.

\section{STRESZCZENIE}

W rozmowie z Ewą Tyszko Maciej Hen opowiada o powstawaniu powieści-kroniki Solfatara, której akcja rozgrywa się w siedemnastowiecznym Neapolu.

\section{Słowa kluczowe}

powieść historyczna, Neapol, Solfatara, Masaniello 


\section{S U M M A RY}

Solfatara - nine days of fisherman's revolution. Ewa Tyszko talks to Maciej Hen Interviewed by Ewa Tyszko, Maciej Hen talks about the creation of his chronicle novel - Solfatara, which is set in 17th century Naples.

\section{Keywords}

historical novel, Naples, Solfatara, Masaniello 